\title{
Algorithmic Capitalism in the Epoch of Digital Reason
}

\author{
Michael A. Peters
}

\begin{abstract}
Algorithmic trading (automated trading, black-box trading, or simply algo-trading) is the process of using computers programmed to follow a defined set of instructions for placing a trade in order to generate profits at a speed and frequency that is impossible for a human trader. The defined sets of rules are based on timing, price, quantity or any mathematical model. Apart from profit opportunities for the trader, algo-trading makes markets more liquid and makes trading more systematic by ruling out emotional human impacts on trading activities.
\end{abstract}

http://www.investopedia.com/articles/active-trading/101014/basics-algorithmic-trading-concepts-and-examples. asp\#ixzz4KI3tX5vx

\begin{abstract}
A small group of high-frequency algorithmic trading firms have invested heavily in technology to leverage the nexus of high-speed communications, mathematical advances, trading, and high-speed computing. By doing so, they are able to complete trades at lightning speeds. High-frequency algorithmic trading strategies rely on computerized quantitative models that identify which type of financial instruments to buy or sell (e.g., stocks, options, or futures), as well as the quantity, price, timing, and location of the trades. These so-called black boxes are capable of reading market data, transmitting thousands of order messages per second to an exchange, cancelling and replacing orders based on changing market conditions, and capturing price discrepancies with little or no human intervention.

— Carol C. Clarke, (2010) “Controlling Risk in a Lightning-Speed Trading Environment: Essays on Issues," The Federal Reserve Bank of Chicago, No 27.
\end{abstract}

\section{"Cybernetic Capitalism"}

Ben Agger was a pioneer. His death on July 14, 2015 was untimely and his passing affected a good many colleagues. His life was a shot in the arm to sociology and political economy. His journal, set up with Tim Luke- Fast Capitalism - is a sociological leader. I was greatly honored to be invited to join the board and although I never met Ben I felt beholden to him as one does to another thinker. The conception of "fast capitalism" is unambiguously political - concerned with the "impact of rapid information and communication technologies on self, society and culture." Agger (1989, 2004, repr. 2016) first theorised fast capitalism and then "faster capitalism" analyzing "domination at the speed of light." As he writes in the Preface:

"A decade after I published Fast Capitalism, I started to theorize the Internet as an important moment of PostFordist, postmodern capitalism (p. v)."

Over the past few years, driven by Agger's examples, I have tried to give different conceptualizations an airing. They have taken the form of a variety of epithets alongside "fast" that attempt to flesh out the original notion adding features of: (i) the application to "fast knowledge" in the universities and the rise of big data and bibliometrics on "performativity" (Besley \& Peters, 2008); (ii) the cybersystem such as the algorithm, network, and mathematical modeling that accompanies high frequency trading ("algorithmic capitalism," financialisation and finance capitalism) (Peters, 2013; Peters, Paraskeva \& besley, 2015); (iii) "cognitive capitalism" as it is part of a wider conception of cybernetic capitalism based on conceptualizations of digital labor (Peters \& Bulut, 20; (iv) cloud capitalism arising 
from cloud computing that emphasises "the systematised virtualisation of data storage and access, the coalescence of power into an instantly available utility, ready for any eventuality" (Coley \& Lockwood, 2012); and, finally, the shift from a notion of biopolitics to what I call "bioinformational capitalism" as the leading edge of informatics and biology (Peters, 2012) that can be viewed within what I call the "epoch of digital reason" (Peters, 2015).

Much of this work runs in parallel with Ben Agger's work on sociontology starting with The Virtual Self, (2003) and Fast Capitalism (1989) as well as Timothy Lukes' early statement in Screens of Power (1990). All of these touch upon the restructuraing of power, knowledge, labor, and capital and all bear some relationship to my work. I am also influenced by other related works that I can mention briefly here including work by Michael Hardt and Antonio Negri, Yann Moulier Boutang, Nick Dyer-Withford's Cybermarx (1989), and Cyberproletariat (2015).

"Cognitive capitalism" (CC) is a theoretical term that has become significant in the critical literature analyzing a new form of capitalism sometimes called the "third phase of capitalism," after the earlier phases of mercantile and industrial capitalism (Boutang, 2011). CC purportedly is a new set of productive forces and an ideology that focuses on an accumulation process centered on immaterial assets utilizing immaterial or digital labor processes and the co-creation and co-production of symbolic goods and experiences in order to capture the gains from knowledge and innovation which is considered central to the knowledge economy. It is a term that focuses on the fundamental economic and media shift ushered in with the Internet as platform and post-Web 2.0 technologies that have impacted the mode of production and the emergence of digital labor. The theory of cognitive capitalism has its origins in French and Italian thinkers, particularly Gilles Deleuze and Felix Guattari's Capitalism and Schizophrenia, Michel Foucault's biopolitics, Hardt and Negri's trilogy Empire, Multitude, and Commonwealth, as well as the Italian 'Autonomist' Marxist movement that has its origins in the Italian Operaismo ('workerism') in the 1960s. More recently CC emanates from a group of scholars centered around the journal Multitudes[1] (http:/ /www.multitudes. net/) (after Hardt \& Negri) established by Boutang in 2000. In this essay I will focus on "algorithmic capitalism" and also make an attempt after clarifying these features to bring to bear a concept of "the epoch of digital reason" (Peters, 2014) as the conceptual frame within which to view these developments.

Cybernetic capitalism is an outcome of changes in the modern concepts of information and communications within a systems framework. Modern cybernetics began with Norbert Weiner who defined the field with his 1948 book Cybernetics: or Control and Communication in the Animal and the Machine where he developed the science of information feedback systems linking control and communication in an understanding of the computer as ideal central nervous system to an apparatus for automatic control' (Wiener, 1948, p.36). The prehistory of the term can be traced back at least to Plato where kybernētēs meaning "steersman" or "governor" (from the Latin gubernator) — the same root as government - was used to refer governing of the city-state as an art based on the metaphor of the art of navigation or steering a ship. Thus, from the beginning the term was associated with politics and the art of government or management as well as with communication and organization.

As an epistemology related to systems and systems philosophy the term functioned as an approach for investigating a wide range of phenomena in information and communication theory, computer science and computerbased design environments, artificial intelligence, management, education, child-based psychology, human systems and consciousness studies. It also was used to characterize cognitive engineering and knowledge-based systems, "sociocybernetics," human development, emergence and self-regulation, ecosystems, sustainable development, database and expert systems, as well as hypermedia and hypertext, collaborative decision-support systems, and World Wide Web studies. It also has been used to talk neural nets, software engineering, vision systems, global community, and individual freedom and responsibility.

Cybernetics is also broadly related to systems philosophy and theory and as Charles François (1999: 203) notes both function as "a metalanguage of concepts and models for transdisciplinarian use, still now evolving and far from being stabilized." François (1999) provides a detailed history of systemics and cybernetics in terms of a series historical stages. First, Precursors (Before 1948)— the "Prehistory of Systemic-Cybernetic Language"—going back to the Greeks and to Descartes in the modern world and ranging across the disciplines.

Second, "From Precursors to Pioneers" (1948-1960) beginning with Weiner who aimed to address the problem of prediction and control and the importance of feedback for corrective steering and including the first generation of modern theorists of cybernetics: Shannon and Weaver (1949), Von Bertalanffy (1950), Kenneth Boulding (1953) as well as von Neumann on the theory of automata, Von Förster biological computer and his collaborators like Ashby (1956), Pask (1975) and Maturana who pursued questions in human learning, autopoiesis and cognition, and Prigogine (1955) on systemics and dissipative structures in complex systems.

Third, "Innovators" (After 1960) beginning with Simon’s (1962) discussion of complexity, Miller's (1978) work 
on living systems, Maturana's work on autopoiesis, i.e. self-production, Mandelbrot's (1977) work on fractal forms, Zadeh (1965) work fuzzy sets and fuzzy logic, Thom's work on the theory of catastrophes, and the development of chaos theory as the study of unpredictable behavior of deterministic non-linear systems that are complex by nature. This stage emphasizes important work on ecology and economics including Odum (1971), Daly (1973) on steadystate economy, Pimentel (1977) on the energy balance in agricultural production (François, 1999: 214).

Fourth, in "Some Significant Recent Contributions" (After 1985) François (1999) examines the Hungarian Csanyi's (1989) work on the 'replicative model of self-organization, Langton (1989) on AL (artificial life), Sabeili's (1991) theory of processes, and McNeil (1993) on the possibility of a better synthesis between physical sciences and living systems. He ends by referencing Prat's (1964) work on the "aura" (traces that remain after the demise of the system), Grassé on "stigmergy" (indirect communication taking place among individuals in social insect societies) and Gerard de Zeeuw (2000) on "invisibility."

If modern cybernetics was a child of the 1950s, catastrophe theory developed as a branch of bifurcation theory in the study of dynamical systems originating with the work of the French mathematician Rene Thom in the 1960s and developed by Christopher Zeeman in the 1970s. Catastrophes are bifurcations between different equilibria, or fixed-point attractors and has been applied to capsizing boats at sea and bridge collapse. Complexity is concerned with theoretical foundations of computer science being concerned with the study of the intrinsic complexity of computational tasks and rests on understanding the central role of randomness. Complexity as an approach to knowledge and market systems now recognizes both the development of global systems architectures in (tele) communications and information with the development of knowledge production systems that increasingly rests not only on the establishment of new and better platforms (sometimes called Web 2.0), the semantic web, new search algorithms, and processes of digitization.

The term "cybernetic capitalism" was first used by Keon Robbins and Frank Webster (1988) in a chapter called "Cybernetic capitalism: Information, Technology and Everyday Life." They use to term to discuss the exploitation of microelectronics and information technology as an economic and political "mobilization" of society, after Bell's "postindustrial society" and the literature on "post-Fordism." They argue that the new information technologies (in 1988!) represent a significant stage in the strategy of "relative mobilization"—one in which technological domination becomes extensively and systematically used in spheres beyond the workplace" (p. 52). The authors make use of Gorz and Foucault to discuss the intensification of work and the increase in societal surveillance where information technologies "constitute a mega-machine, a systematic and integrated mechanism" where "information/knowledge becomes a site of the struggle for power (p. 72).

In 1994 Jerry Harris and Carl Davidson as part of The Chicago Third Wave Study Group in "The Cybernetic Revolution and the Crisis of Capitalism" argued "New technologies have changed the face of capitalism, affecting the economic base, the relations of production, and are impacting political strategy." Douglas R. Holmes \& George E. Marcus (2006) write of para-ethnography and the rise of the symbolic analyst:

Fast-capitalism thus designates the circumstances under which knowledge is created and effaced as the communicative space of the nation-state is eclipsed and our subjects; and we too must think and act within a communicative space mediated increasingly by supranational markets (p. 43).

In a previous paper I attempted to develop a grounded and literature-based analysis of the main forms of "new" or "advanced" capitalism referred to by theorists and scholars (Peters et al, 2009). I called the overall conception "cybernetic capitalism" and identified five major categories that fell under the heading. "Cybernetic" is a somewhat dated term and some would argue that the concept is also outmoded but there are good reasons to hang on to the term in its fourth and fifth generation iterations in how they apply to markets and to modern capitalism.

\title{
Forms of Cybernetic Capitalism
}

\author{
1. Informational Capitalism: The Nature of Information/Knowledge \\ "Informational” (Castells, Fuchs, Fitzpatrick, Schmiede) "Digital” (Schiller \& McChesney), “Cyber” (Dyer-Witherford), \\ "Fast” (Agger) "High-tech” (Haug), "Academic Capitalism” (Slaughter), "Knowledge Capitalism” (Peters \& Besley)
}

2. Cultural Capitalism: The Change of Culture

Volume $14 \bullet$ Issue $1 \bullet 2017$

FAST CAPITALISM 
"New Culture" (Sennett), "Knowing Capitalism" (Thrift), "New Spirit" (Boltanski \& Chiapello), "Cultural Economy" (Pryke \& Gay) "Cognitive -Cultural” (Scott)

\section{Cognitive Capitalism: Immaterial Labor}

“Cognitive Capitalism” (Moulier Boutang, Vercellone, De Angelis \& Harvie, Fumagalli \& Lucarelli), “Affective Capitalism” (Massumi, Dowling, Hardt), "Immaterial Labor" (Marx, Negri \& Hardt), "Semio-capitalism" (Beradi), "Education and digital labour” (Peters \& Bulut)

\section{Finance Capitalism: "Financialization"}

"Finance capitalism" (Forster, Glyn, Leyshon \& Thrift, Vestergaard), "financialization" (Epstein, Vasudevan, BresserPereira, Palley), Global financial crisis and education (Peters)

\section{Biocapitalism: "Biopolitics"}

Biopower, biopolitics (Foucault) Biocapitalism (Deleuze \& Guattari, Rajan), Bioinformational capitalism (Peters)

Each of these conceptions emphasize an aspect of the conceptual change involved in the emergence of a global information system: speed, acceleration, mobilization, location, network, circulation, algebrification, formalization, mathematical modeling, bioinformatics, organicity. These features have become increasingly more evident over the last couple of decades as finance capitalism has developed and equity markets have become increasingly reliant on algorithms.

\section{Algorithmic Capitalism ${ }^{[2]}$}

The word algorithm comes from the name of the 9th century Persian Muslim mathematician Abu Abdullah Muhammad ibn Musa Al-Khwarizmi. The word algorism originally referred only to the rules of performing arithmetic using Hindu-Arabic numerals but evolved via European Latin translation of Al-Khwarizmi's name into algorithm by the 18 th century. The use of the word evolved to include all definite procedures for solving problems or performing tasks.

\section{History of Algorithms and Algorithmics \\ (http://www.scriptol.com/programming/algorithm-history.php0}

Khwarizmi, Abu Jafar Muhammad ibn Musa al- (d. ca. 850 )

Mathematician, astronomer, and geographer. Synthesized extant Hellenic, Sanskritic, and cuneiform traditions to develop algebra, a term derived from the title of one of his books (containing the term al-jabr, meaning "forcing" [numbers). Introduced Arabic numerals into the Latin West, based on a place-value decimal system developed from Indian sources. The word algorithm is derived from a Latin corruption of his name.

\section{Oxford Islamic Studies Online}

(http://www.oxfordislamicstudies.com/article/opr/t125/e1305)

Algorithmic capitalism and its dominance of the market increasingly across all asset classes has truly arrived. Rob Iati (July 10, 2009) writing for Advanced Trading asserts:

Algorithms account for more than $25 \%$ of all shares traded by the buy side today - a number steadily rising for several years now. However, the incredible capabilities offered by technology have given meteoric rise to a relative few high-frequency proprietary trading firms that now wield far greater influence on the markets today than most people recognize. The familiar names of Lehman, Bear and Merrill are being replaced by less familiar ones like Wolverine, IMC and Getco... highfrequency trading firms, which represent approximately $2 \%$ of the 20,000 or so trading firms operating in the U.S. markets today, account for $73 \%$ of all U.S. equity trading volume.[3]

Writing almost a decade ago Iati (2009) indicates that value of high-frequency algorithmic trading relies on "a 
real-time, collocated, high-frequency trading platform... where data is collected and orders are created and routed to execution venues in sub-millisecond times."

Algorithmic capitalism is an aspect of informationalism or informational capitalism or "cybernetic capitalism," a terms that I prefer because it speaks to the genealogy of postmodern capitalism and recognizes more precisely the cybernetic systems similarities among various sectors of the postindustrial capitalist economy in its third phases of development-from mercantilism, industrialism to cybernetics-linking the growth of the multinational infoutilities (e.g., Goggle, Microsoft, Amazon) and their spectacular growth in the last twenty years, with developments in biocapitalism and the informatization of biology, and fundamental changes taking place with algorithmic trading and the development of so-called financialization.

It is in this context that also we can talk of "cloud capitalism" that is recentralizing the Net and creating large scale monopolies in the knowledge economy, on a vastly larger scale than anything imagined possible in the industrial era. Take for example Google's project of digitizing millions of books that will make its digital library bigger than the Library of Congress. By doing so as Charles Leadbeater (2010) argues "Google will acquire huge power over the future of publishing. It will be able to head off potential competition from other databases of digital books." As he goes on to explain: "Google is the first and most successful exponent of a new kind of economic power: cloud capitalism." He suggests that the Internet that the cloud capitalists want to give us is quite different from that of the "information superhighway" or "cyberspace":

In cloud computing, our data - emails, documents, pictures, songs and software - will be stored remotely in a digital cloud hanging above us, always there to access from any device: computer, television, games console, hand-held and mobile. We should be able to draw down as much or as little of the shared cloud as we need (http://www.guardian.co.uk/ technology/2010/feb/07/cloud-computing-google-apple).

Leadbeater raises questions about the way cloud capitalism aims at complete control that ultimately excludes other databases while maximizing revenues and the capacity of clouds to hold vast amounts of data on us that occludes the interests of citizens and eludes the control of governments. We might see "cloud capitalism" as an aspect of a wider phenomenon of cognitive or cybernetic capitalism.

There is no doubt that speed is a central feature of global markets and of global networked capitalism. Agger builds on theorists like Paul Virilio (2006) who sees speed as a determinant of future society and economy. Some evidence for this philosophical orientation can be gained from HFT-high frequency trading-that is a kind of algorthmic trading characterised by high turnovers that uses a platform to transact large numbers of trades in very short time periods, shaving pennies off lightning bulk trades every mcro-second. Electronic exchange only came into being in 1998; by 2009 HFT comprised over 70\% of all equity trading. It has since retreated somewhat. Yet, since its introduction the speed of HFT has increased from seconds per trade to milli- and microseconds. One investment analyst advises that

“....algo-traders make trades in 10 milliseconds or less. some say it's as fast as half a millionth of a second - that's more than a million times faster than the human brain can process a decision." [4] He goes on to write:

Today, high-frequency trading is even faster. According to Aequitas Innovations, the parent company of Canada's newest stock exchange dedicated to leveling the playing field for investors, $11 \%$ of all 2014 observable orders in the Canadian marketplace lasted less than one millisecond. In other words, by the time you blink your eye and before you even place a trade, a high-frequency trader may have already processed 400 orders ahead of you.

In a paper published online some years ago (Peters, 2012) entitled "Algorithmic Capitalism and Educational Futures: Informationalism and the Googlization of Knowledge"[5] I commented upon the rise of a new kind of capitalism that Agger had been one of the first to name and to begin to scrutinize its social consequences:

\footnotetext{
Algorithmic capitalism and its dominance of the market increasingly across all asset classes has truly arrived. It is an aspect of informationalism (informational capitalism) or "cybernetic capitalism," a term that recognizes more precisely the cybernetic systems similarities among various sectors of the post-industrial capitalist economy in its third phase of development - from mercantilism, industrialism to cybernetics - linking the growth of the multinational info-utilities (e.g., Goggle, Microsoft, Amazon) and their spectacular growth in the last twenty years, with developments in biocapitalism and the informatization of biology, and fundamental changes taking place with algorithmic trading and the development of so-called financialization.
}

Speed and velocity are the main aspects of a new finance capitalism that operates at the speed of light based on 
sophisticated "buy" and "sell" algorithms. Already researchers have demonstrated that data transfer using a single laser can send 26 terabits per second down an optical fiber and there are comparable reports that lasers will make financial "high-frequency" trading even faster.

Tyler Falk (2013) reports on "How lasers will make financial trading even faster":

In the world of computerised financial trading, every second counts and superfast fibre-optic networks may no longer be quick enough. Laser beam technology originally developed for the military is being rolled out to shave time off trades. It will compete with new microwave networks that are increasingly being used by traders. http://www.bbc.com/news/ technology-22380611

Assignment, the BBC program explored HFT and the behavior of some banks utilizing super-fast, computerized share-dealing systems that enable them to process nearly a half a million share deals every second, earning the sector some 21 billion in 2015 and giving bank using this technology and unfair advantage in the marketplace.[6] Concerns have been raised about computerized financial services that allow high frequency traders to get faster access to information allowing firms to create sophisticated computer programs to buy and sell stocks in milliseconds, faster than any human.[7]

Western modernity (and developing Global systems) exhibit long-term tendencies of an increasing abstraction described in terms of formalization, mathematicization, aestheticization and biologization of life. These are characteristic of otherwise seemingly disparate pursuits in the arts and humanities as much as science and technology and driven in large measure through the development of logic and mathematics especially in digital systems. Much of this rapid transformation of the properties of systems can be captured in the notion of "bioinformational capitalism" that builds on the literatures on "biocapitalism" and "informationalism" (or "informational capitalism") to develop the concept of "bio-informational capitalism" in order to articulate an emergent form of capitalism that is self-renewing in the sense that it can change and renew the material basis for life and capital as well as program itself. Bioinformational capitalism applies and develops aspects of the new biology to informatics to create new organic forms of computing and self-reproducing memory that in turn have become the basis of bioinformatics.

The notion of "algorithmic capitalism" as I have previously described it is "an aspect of informationalism" (informational capitalism) or "cybernetic capitalism," a term that recognizes more precisely the cybernetic systems similarities among various sectors of the post-industrial capitalist economy in its third phase of development from mercantilism, industrialism to cybernetics—-linking the growth of the multinational info-utilities (e.g., Goggle, Microsoft, Amazon) and their spectacular growth in the last twenty years, with developments in biocapitalism and the informatization of biology. Fundamental changes are taking place with algorithmic trading and the development of so-called financialization."

I used the notion to examine and explain the phenomenon of the "Flash Crash" when the Dow Jones lost 700 points (some $\$ 800$ billion)—one of its biggest one-day falls in history—and recovered within minutes.

Algorithmic trading is sometimes seen as an explanation of market volatility especially when risk is not transparent or able to be effectively tracked and monitored. Automated buy-sell programs now account for over 80 per cent of all US equity trading. Increasingly, global information systems that operate at the speed of light are now harnessed by HFT (high frequency trading) firms to create Automated Trading Desks that are capable of trading hundreds of millions of shares daily. So-called "quant trading," after "quantitative trading programs" are now designed by mathematicians and underlie HFT, where stocks are held often for only microseconds. The staggering growth of the finance industry sometimes referred to as "financialization" represents a set of overlapping processes that refer not only to the rapid expansion of the financial sector of the capitalist system-to the growth of financial institutions of all kinds—but also to a qualitative change in the mode of production where banking systems jettison traditional banking practices to become commercial investors and multinational corporations develop as financial institutions able to invest and trade directly in financial markets.

\section{The Epoch of Digital Reason ${ }^{[8]}$}

Global finance capitalism (and "financialisation") is but one prominent and rapidly growing aspect of "cybernetic capitalism." Western modernity and the developing global systems spawned by Western (neo)liberal capitalism exhibit long-term tendencies of an increasing abstraction that can be described in terms of long-term modernization 
processes including the "formalization," "mathematicization," "aestheticization," and "biologization" of everyday life (Peters, Britez \& Bulut, 2009; Peters, 2011). These cybernetic processes are characteristic of otherwise seemingly disparate pursuits in the arts and humanities as much as science and technology and have been driven in large measure through the development of logic and mathematics especially in the world architecture of emerging global digital systems. In this respect, we can talk of the emergence of digital reason and of the university in the epoch of digital reason. By this description I mean principally a set of developments in foundations of mathematics and the algebra of logic that predate the founding of cybernetics as a discipline with the 1946 and 1953 conferences sponsored by the Josiah Macy, Jr. Foundation in New York City on the subject of "Circular Causal and Feedback Mechanisms in Biological and Social Systems" (Umpleby, 2005). The prehistory of cybernetics that result in the problematic history of the development of digital logic including Boolean algebra, gates that process logic signals, switching theory, flip-flops and memory elements that store logic signals and in general the representation of binary information in physical systems. In this tangled genealogy George Boole (1847) wrote The Mathematical Analysis of Logic that provided the calculus for a two-valued logic, applying algebra to logic, representing true or false within assertion logic that is the basis for all modern programming languages and digital electronics. Claude Shannon discovered that the rule of Boolean algebra could be applied to switching circuits and introduced switching algebra in order to design circuits of logic gates. (The algebra of 0 and 1 was applied to electrical hardware comprising logic gates to form a circuit diagram).[9]

Digital reason is a wider and a more philosophical notion than digital logic, named here in the tradition of Kant and Foucault. It governs the historical emergence of a techno-epistemological epoch that is so recent but indicates a deep transformation of the knowledge economy or knowledge capitalism, society and knowledge institutions. Its concepts are the concepts of speed and velocity_involving limits of the physics of light—as well as system, feedback and control. Much of this rapid transformation of digital logic and the properties of systems can be captured in the notion of "algorithmic capitalism" (Peters, 2012a,c, 2013) as an aspect of informationalism (informational capitalism) or "cybernetic capitalism," a term that recognizes more precisely the cybernetic system similarities among various sectors of the post-industrial capitalist economy in its third phase of development—from mercantilism, to industrialism and finally to cybernetics - linking the growth of the multinational info-utilities (e.g., Goggle, Microsoft, Amazon) and their spectacular growth in the last twenty years, with developments in biocapitalism (the informatization of biology and biologization of information), and fundamental changes taking place in the nature of the market with algorithmic trading and the development of so-called "financialization".

\section{Biologizing Digital Reason}

The third phase of "cybernetic capitalism" itself has undergone further development from first to fifth generation. I described above the first four generations to the point of complexity theory. The fifth is what I call "bioinformationalism" representative of bioinformational capitalism (Peters, 2012) that articulates an emergent form of capitalism that is self-renewing in the sense that it can change and renew the material basis for life and capital as well as program itself. This represents a massive change to the notion of digital reason as also a biological notion-biologizing digital reason. Bio-informational capitalism applies and develops aspects of the "new biology" to informatics to create new organic forms of computing and self-reproducing memory that in turn has become the basis of bioinformatics. I begin with a review of the successes of the "new biology," focusing on Craig Venter's digitizing of biology and the creation of new life from the digital universe and provides a brief account of bioinformatics before brokering and discussing the term "bioinformational capitalism."

Genomic capitalism represents a phase of global biocapitalism that, when harnessed with a new generation of information processing, itself organically enhanced, comprises a 'bio- informationalism' that expresses a new kind of utopian perfectionism about the possibilities for a new age of genetic self-renewing capitalism that is capable of programming itself (Peters, 2012: 99).

As Venter (2008) claimed:

we've been digitizing biology, and now we're trying to go from that digital code into a new phase of biology, with designing and synthesizing life.... We've been digitizing it now for almost 20 years. When we sequenced the human genome, it was going from the analog world of biology into the digital world of the computer. Now we're trying to ask: can we regenerate 
life, or can we create new life, out of this digital universe?[10]

The development of the new biology has in large measure been possible through the application of informatics to biology and more recently of the new biology to informatics, using data-intensive-so-called "big data" — to develop a "evo-devo" program that integrates biological theory across the hierarchy of life. This involves the development of a dialectic of information and biology ("bioinformatics") as a scientific logic and rationality that leads to the biologization of the digital (in the long term) and an informatization of biology.

David M. Berube reviewing J. Craig Venter's (2013) Life at the Speed of Light: From the Double Helix to the Dawn of Digital Life and G. Church and E. Regis' Regenesis: How Synthetic Biology Will Reinvent Nature and Ourselves (2012) provides the following gloss:

We have entered the digital age of synthetic biology. With biotechnology and advanced computer information systems converging, we are at a point when we can design gene sequences, connect them into more complicated arrays, and insert them into the DNA of a developing organism, resulting in life that had not naturally evolved in the global ecosystem (p. 428).

Synthetic biology harnesses computer power in the production of genomic scientific capitalism augmenting the capacity of digital reason through organic memory and the possibility of new forms of bioinformatics. There are close connections between biology and information where forms of informational biology and biological information demonstrate how the concept of information since the 1950s has made its way into the heart of biological studies. Theorists in biology have utilized Claude Shannon's concept of information as described in his mathematical communication theory and more recently moved to introduce the notion of teleosemantics, signaling systems of the genetic code and the role of information in evolutionary processes.

My speculation is that the biologization of digital reason is a distinct phenomenon that is at an early emergent form that springs from the application of digital reason to biology and the biologization of digital processes. In this space we might also talk of digital evolution, evolutionary computation, and genetic algorithms.

Most accounts of digital capitalism that emphasize algorithmic governance or cloud storage tend to prefigure a notion that falls under what I call "digital reason" that instrumentalizes knowledge and information as a stage in the evolution and transformation of modern capitalism. Thus, Luciana Parisi (2016) in a lucid account argues:

\begin{abstract}
Algorithmic cognition is central to today's capitalism. From the rationalization of labor and social relations to the financial sector, algorithms are grounding a new mode of thought and control. Within the context of this all-machine phase transition of digital capitalism, it is no longer sufficient to side with the critical theory that accuses computation to be reducing human thought to mere mechanical operations. As information theorist Gregory Chaitin has demonstrated, incomputability and randomness are to be conceived as very condition of computation. If techno-capitalism is infected by computational randomness and chaos, the traditional critique of instrumental rationality therefore also has to be put into question.
\end{abstract}

She foregrounds the emergence of cognitive labor as the dominant form and also presages the financialization of life and the dominance of finance culture. Yet now we are now entering and biocognitive era of capitalism where "machinic phyla are agents productive of being" featuring "ontological heterogenesis" and "collective assemblages of subjectivity" (Guattari 2011: 50).[11] As Charles T. Wolfe (2016: 175) argues a thesis concerning the "social brain" "Biological, aesthetic and we might add, cerebral machines are constitutive parts of the production of subjectivity, rather than its 'other." He reminds us of one kind of materialism that indicates "Brains are culturally sedimented, permeated in their material architecture by our culture, history, and social organization; and this sedimentation is itself reflected in cortical architecture"(p. 177), where creating new circuits in art or philosophy, as Deleuze contends, "means creating them in the brain" (cited in Wolfe, p. 179). Thus, the brain is ontological opening to shaping that advertises a new neuroplasticity able to escape biological determinism.

In this new era of "biocognitive capitalism" - what I refer to as "biologizing digital reason" - we encounter the realm of augmented intelligence and also "deep learning" both of which have critical consequences for digital labor. Matteo Pasquinelli (2016: 203) reminds us:

Augmented intelligence must be distinguished from artificial intelligence, which implies a complete autonomy of machine intelligence from human intelligence despite sharing a logical and technological ground; and from swarm intelligence, which describes decentralized and spontaneous forms of organization in animals, humans, and algorithmic bots...

The second machinic moment of automation as a discernible stage that may not entirely detach itself from 
augmented intelligence has the power to go beyond any human-machine interface into the realm of deep learning where human labor and life is not a requirement for production. This is the stage where automation reaches its limit creating autonomous technological learning systems that are able to learn from large amounts of data that are feed to it in a continuous stream and is based on incremental self-improvement in machine performance.

\section{Endnotes}

1. Multitude is a political concept at the limits of sovereign power dating from Machiavelli and Spinoza naming a population that has not entered into a social contract and retained it capacity for political selfdetermination and, after Hardt and Negri, resistance against global systems of power. The journal offers the following description: "The concept of "multitudes" refers to the immanence of subjectivities (rather than "identities") acting in opposition to established power structures and mapping the way for new futures.'

2. This section draws on my "Speed, Power and the Physics of Finance Capital" http://www.wpfdc.org/ blog/economics/18793-speed-power-and-the-physicsof-finance-capitalism

3. See http://advancedtrading.com/algorithms/show Article.jhtml?articleID=218401501 .

4. See http://www.equedia.com/how-fast-is-high fre quency-trading/

5. See http://www.truth-out.org/news/item/8887algorithmic-capitalism-and-educational-futures- informationalism-and-the-googlization-of-knowledge

6. Listen to Assignment at http://www.bbc.co.uk/ programmes/p004vqkc

7. See the concerns expressed by Eric Schneiderman New York's attorney general who has called for curbs at http://www.bbc.com/news/business-26637465

8. This section is based on a couple of paragraphs from Peters (2015).

9. See Burris (2013) on "The Algebra of Logic Tradition"; O'Regan (2008) on the history of computing; and Stankovic \& Astola (2011) on switching theory.

10. See http://www.ted.com/talks/craig_venter_is_ on_the_verge_of_creating_synthetic_life.html

11. In particular, see the work of Andrea Fumagalli who holds that cognitive biocapitalism refers to a larger set of meanings than cognitive capitalism (Fumagalli and Morini, 2013).

\section{References}

Agger, B. (1998) Fast Capitalism . Champaign, Il, University of Illinois Press.

Agger, B. (2003) The Virtual Self: A Contemporary Sociology . Oxford, Blackwell.

Agger, B. (2004) Speeding Up Fast Capitalism: Cultures, Jobs, Families, Schools, Bodies . London, Routledge.

Besley, T. \& Peters, M. A. (2006) The Theatre of Fast Knowledge: Performative Epistemologies in Higher Education, Review of Education, Pedagogy, and Cultural Studies, 27:2, 111-126.

Burris, Stanley, (2013). The Algebra of Logic Tradition, The Stanford Encyclopedia of Philosophy (Summer 2013 Edition), Edward N. Zalta (ed.), URL = <http://plato.stanford.edu/ archives/sum2013/entries/algebra-logic-tradition/>.
Coley, R. and Lockwood, D. (2012) Cloud Time: The Inception of the Future Zero Books.

Dyer-Witheford, N. (1989)Cyber-Marx: Cycles and circuits of struggle in high technology capitalism . Champaign, Il., University of Illinois Press.

Dyer-Witheford, N. (2015)Cyberproleatriat: Global Labour In The Digital Vortex . Chicago, Chicgo of University Press.

Fumagalli, A. and Cristina Morini (2013), Cognitive Biocapitalism, social reproduction and the precarity trap: why not basic income?, in Knowledge Cultures, 1 (4), 2013, pp. 106-126.

Guattari, Félix (2011). On Contemporary Art (1992 interview). In The Guattari Effect, edited by Éric Alliez and Andrew Goffey, 40-53. London: Continuum 
Lafontaine, Céline (2007) The Cybernetic Matrix of 'French Theory', Theory, Culture \& Society, 24(5), 27-46. http://dx.doi. org $/ 10.1177 / 0263276407084637$

Luke, T. W. (2005) Scanning Fast Capitalism: Quasipolitan Order and New Social Flowmations. At http://www.uta.edu/huma/ agger/fastcapitalism/1_1/luke.html

Luke, T. W. (2005) Screens of Power: Ideology, Domination, and Resistance in Informational Society . Champaign, Il., University of Illinois Press.

Lyotard, Jean-François (1984) The Postmodern Condition: a report on knowledge, tr. Geoff Bennington \& Brian Massumi. Minneapolis: University of Minnesota Press.

MacKenzie, D. (2001) Physics and Finance: S-Terms and Modern Finance as a Topic for Science Studies, Science, Technology, \& Human Values, Vol. 26, No. 2: pp. 115-144

Mandel, E. (1975) Late Capitalism. London: Humanities Press.

Matthewman, S. (2013) Accidentology: A Critical Assessment of Paul Virilio's Political Economy of Speed, Cultural Politics, Volume 9, Issue 3, November 2013, pp. 280-295.

O’Regan, Gerard (2008). A brief history of computing .Springer.

Parisi, L. (2016) Instrumental Reason, Algorithmic Capitalism, and the Incomputable. In Pasquinelli, M (2016) Alleys of Your Mind: Augmented Intelligence and Its Traumas . Lüneburg, Meson Press, pp. 125-139.

Pasquinelli, M (2016) Alleys of Your Mind: Augmented Intelligence and Its Traumas . Lüneburg, Meson Press.

Pasquinelli, M (2016)Keyword: Augmented Intelligence. In Pasquinelli, M (2016) Alleys of Your Mind: Augmented Intelligence and Its Traumas . Lüneburg, Meson Press pp. 203-210.

Peters, M.A. (2012a) Cybernetics. In Helmet K. Anheier \& Mark Juergensmeyer (Eds.) The Encyclopedia of Global Studies, Sage, http://knowledge.sagepub.com/view/globalstudies/n117.xml

Peters, M.A. (2012b) Postmodern Educational Capitalism, Global Information Systems and New Media Networks, Policy Futures in Education Volume 10 Number 1: 23-29.

Peters, M.A. (2012c) Algorithmic Capitalism and Educational Futures: Informationalism and the Googlization of Knowledge, TruthOut, http://truth-out.org/news/item/8887-algorithmiccapitalism-and-educational-futures-informationalism-and-thegooglization-of-knowledge
Peters, M.A. (2013) Speed, Power and the Physics of Finance Capitalism, TruthOut, http://www.truth-out.org/news/ item/16960-speed-power-and-the-physics-of-financecapitalism

Peters, M.A. (2015) The University in the Epoch of Digital Reason: Fast Knowledge in the Circuits of Cybernetic Capitalism. In: Universities in the Flux of Time: An exploration of time and temporality in University Life, Paul Gibbs, Oili-Helena Ylijoki, Carolina Guzmán-Valenzuela, Ronald Barnett (Eds.). (London \& New York, Routledge.

Peters, M.A. \& Bulut, Ergin (Eds) (2011) Cognitive Capitalism, Education and Digital Labor. New York: Peter Lang.

Peters, M.A. \& Roberts, P. (2011) The Virtues of Openness: education, science and scholarship in the digital age. Boulder, CO: Paradigm.

Peters, M.A., Britez, R. \& Bulut, E. (2009) Cybernetic Capitalism, Informationalism And Cognitive Labor, Geopolitics, History, and International Relations, 1 (2): 11-40.

Peters, M.A., Murphy, P. \& Marginson, S. (2009) Creativity and the Global Knowledge Economy. New York: Peter Lang.

Peters, M.A., Paraskeva, J. \& Besley, T. (2015) The Global Financial Crisis and Educational Restructuring. New York, Peter Lang.

Radomir S. Stankovic; Jaakko Astola (2011) From Boolean Logic to Switching Circuits and Automata: Towards Modern Information Technology.Springer.

Robbins, K. and Webster, F. (1988) Cybernetic Capitalism: Information, Technology, Everyday Life. In The Political Economy of Information, Vincent Mosko and Janet Wasko, eds., Madison: The University of Wisconsin Press: 45-75, http://glotta.ntua.gr/IS-Social/CyberCulture/ RobinsCybernetic.html.

Umpleby, S. (2005) A History Of The Cybernetics Movement in The United States, Journal of the Washington Academy of Sciences, Vol. 91, No. 2, Summer 2005, pp. 54-66.

Wolfe, C.T. (2016) Brain Theory Between Utopia and Dystopia: Neuronormativity Meets the Social Brain. In Pasquinelli, M (2016) Alleys of Your Mind: Augmented Intelligence and Its Traumas . Lüneburg, Meson Press, pp. 173-186 